\title{
Biochemical Differentiation of Pseudomonas fluorescens of Assam Soil and their Utility in Management of Bacterial Wilt of Solanaceous Crops
}

\author{
Thalhun L. Kipgen* and L.C. Bora \\ Department of Plant Pathology, Assam Agricultural University, Jorhat-785013, Assam, India \\ *Corresponding author
}

\author{
A B S T R A C T
}

\section{Keywords \\ Ralstonia \\ solanacearum, \\ Pseudomonas \\ fluorescens, \\ Isolate, \\ Bioagent, \\ Wilt, \\ Population \\ dynamics. \\ Article Info \\ Accepted: \\ 26 May 2017 \\ Available Online: \\ 10 June 2017}

Potential of antagonistic rhizobacteria Pseudomonas fluorescens in the management of bacterial wilt of different solanaceous crop, viz., tomato, brinjal and chilli caused by Ralstonia solanacearum was evaluated under in vitro and in vivo conditions. A total of twenty five (25) P. fluorescens isolates were collected from different rhizospheric soils of Assam and their characterization was done. Five (5) isolates produced fluorescents yellow green or bluish green diffusible pigment of variable intensities on King's B medium under UV light $(365 \mathrm{~nm})$. These five isolates were identified to be classified under Biovar I (PfA1, Pf - A4, Pf - A7), Biovar II (Pf-A6) and Biovar III (PfA8) respectively, according to their biochemical differentiations. Dual culture tests using paper disc assay revealed that the strains Pf-A8 could cause highest inhibition in growth of $R$. solanacearum (tomato) by 76.0 per cent, 63.0 per cent (Brinjal) and 72.2 per cent (Chilli), respectively. Application of Pf-A8 based bio formulation as seed treatment, root treatment and soil application exhibited lowest wilt incidence $(1.0 \%)$ in tomato plants, 2.0 per cent in brinjal plants and 4.0 per cent in chilli plants, respectively. The population dynamics of the pathogen and antagonist in crop rhizosphere soils showed significantly increase in all treatments as compared to controls. Corresponding to the enhancement of $P$. fluorescens population in the treated rhizosphere soil there was decline of $R$. solanacearum population. The correlation studies established a negative correlation between PWI and population density of $P$. fluorescens as well as between population densities of $R$. solanacearum and $P$. fluorescens. The finding furthers supports the biocontrol properties of the antagonistic strain $P$. fluorescens. The isolate Pf-A8 strains could serve as promising bioagent although needs further in situ investigations.

\section{Introduction}

The bacterial wilt solanaceous crops caused by Ralstonia solanacearum is an important soil borne bacterial plant pathogen with worldwide distribution and a wide host range of more than 200 species in 50 families (Hayward, 1991). Some of its economically important plant hosts include tomato, potato, eggplant, pepper, tobacco, banana, chilli, and peanut (French and Sequeira, 1970).Tomato
(Lycopersicum esculentum Mill), Brinjal (Solanum nigrum) and chilli (Capsicum annum $\mathrm{L}$ ) are some popular and widely grown vegetable crops in the world and are major source of income for the small and marginal farmers. The major constraint in their production is the bacterial wilt disease as it causes severe plant mortality and yield loss up to an extent of 90 to 100 per cent (Kishun, 
1989). R. solanacearum a ubiquitous soil borne bacterial pathogen, and its management by single method of control is very difficult. Environmental damage, cost and high labour inputs are some of the drawbacks of conventional chemointensive methods of disease management. Use of biological control by antagonistic microorganisms could be important alternative management technique that can be integrated with other practices for effective disease management at the field level. Primarily Pseudomonas fluorescens has been identified as an important microorganism with ability for plant growth promotion, increase yield and reduce severity of many plant diseases (Wei et al., 1996). The present study was made to isolate new and aggressive native strains of $P$. fluorescens from Assam soil, characterize them and evaluated their potential biocontrol activity for suppressing bacterial wilt of solanaceous crops.

\section{Materials and Methods}

The experiments were carried out in the laboratory and Green House of the Department of Plant Pathology, Assam Agricultural University, Jorhat. Cultures of $R$. solanacearum were isolated from infected tomato, brinjal and chilli plants using Triphenyl Tetrazolium Chloride (TTC) agar medium. The virulent colonies characterized by dull white colour, fluidal, irregularly round with light pink centres were further streaked on TTC medium to get pure colonies of the bacterium. Morphological, cultural and biochemical characterization were done inside the laboratory of Department of Plant Pathology, AAU Jorhat. Inoculums was prepared by using $24 \mathrm{hr}$ old bacterial suspension, adjusted to optical density (O.D) 0.5 in Spectrophotometer (Spectronic 20) using blue filter $(425 \mathrm{~nm})$ to obtain a bacterial population of 1 x $108 \mathrm{cfu} / \mathrm{ml}$.
Seeds of tomato (cv. Pusa Ruby), brinjal (cv. Pusa Kranti) and chilli (cv. Bor Bhut) were sown on earthen pots $(26 \mathrm{~cm} \times 22 \mathrm{~cm} \times 32 \mathrm{~cm})$ simulating nursery beds. The pots were filled with sand and potting medium in the ratio 1:3 respectively. For the pathogenicity test, a set of three 30 days old brinjal plants were injected with suspension of $R$. solanacearum (@ $1 \times 108 \mathrm{cfu} / \mathrm{ml}$ ) following root inoculation technique (Winstead and Kelman, 1952). Another set of three seedlings were inoculated with sterile distilled water to serve as control.

\section{Isolation and characterization of $P$. fluorescens}

Isolates of $P$. fluorescens were collected from the rhizospheric soils sampled from different districts of Assam. One gram of soil from each rhizospheric sample was mixed with 10 $\mathrm{ml}$ of sterile water and vortex for $10 \mathrm{~min}$ to obtain standard soil suspension. Isolation of $P$. fluorescens was made by following serial dilutions (10-1 to 10-8) using King's B medium. A well separated individual colonies with fluorescent yellowish-green and fluorescent yellow pigments were marked and detected by viewing under UV light (366 nm) after $24 \mathrm{hr}$. The individual colony was picked up and streaked on to fresh KMB slants. The slants were covered with mineral oil and preserved at $4^{\circ} \mathrm{C}$ for further use.

For morphological, cultural, physiological and biochemical characterization of $P$. fluorescens, pure cultures of each isolate were streaked on fresh King's B agar Petri plates separately for colony development and gram staining, examined for shape, colony elevation, colony edge and pigment production.

Biochemical properties like were studied following the guidelines described in Bergey's Manual of Determinative Bacteriology 9th edition (Holt et al., 2000; 
Maki et al., 2011). Production of HCN and siderophore test by the bacterial antagonists were also determined (Payne, 1994).

Aggressive strains of $P$. fluorescens based on their ability to produce fluorescent yellowishgreen and fluorescent yellow pigments, $\mathrm{HCN}$ production, siderophore production, etc., were identified and selected to test their antagonistic property against $R$. solanacearum in vitro and use as bio formulation for management of bacterial wilt disease in tomato, brinjal and chilli in vivo.

\section{In vitro evaluation of $\boldsymbol{P}$. fluorescens against R. solanacearum}

In vitro tests for evaluation of $P$. fluorescens against $R$. solanacearum was conducted following dual culture method (Anuratha et al., 1990). $R$. solanacearum was grown in conical flask containing $40 \mathrm{ml}$ of nutrient broth, incubated at $25^{\circ} \mathrm{C} \pm 1^{\circ} \mathrm{C}$ for $48 \mathrm{hrs}$. One $\mathrm{ml}$ of bacterial suspension was mixed with 15 $\mathrm{ml}$ of molten KMB and poured onto a sterile Petri plate to get bacterial lawn. Sterile filter paper disc $(0.8 \mathrm{~cm})$ was laid on the agar surface at the centre of the Petri plate and $25 \mu \mathrm{l}$ of $48 \mathrm{~h}$ old broth cultures of selected $P$. fluorescens were applied to each disc. Plates were then incubated at $25^{\circ} \mathrm{C} \pm 1^{\circ} \mathrm{C}$ for $120 \mathrm{hrs}$. The diameter of the inhibition zones around the disc was measured using antibiotic zone scale.

The efficacy of $P$. fluorescens based bio formulation in controlling bacterial wilt of tomato, brinjal and chilli were evaluated in the greenhouse using susceptible variety viz., tomato (var. Pusa Ruby), brinjal (var. Pusa Kranti) and chilli (var. Bor Bhoot), following complete randomized design (CRD). For preparation of substrate based bio formulation of aggressive $P$. fluorescens, finely sieved talcum powder was filled in $1 \mathrm{~kg}$ capacity polypropylene (PP) bags and sterilized at $121^{\circ} \mathrm{C}$. Pure cultures of $P$. fluorescens grown in KB slants were washed with sterile distilled water and $15 \mathrm{ml}$ of this suspension was added aseptically to 1 lit of Nutrient broth contained in conical flask. The flask after thorough stirring was incubated at $28 \pm 1{ }^{\circ} \mathrm{C}$ for $72 \mathrm{~h}$ to obtain a bacterial concentration of $1 \times 107 \mathrm{cfu} / \mathrm{ml}$. Then $15 \mathrm{ml}$ of the bacterial cells were inoculated in to the PP bags containing talcum powder. To facilitate greater adherence property of the substrate, 10 $\mathrm{ml}$ of sticker, carboxy-methyl cellulose (CMC @ $1 \%$ ) was added aseptically. Similarly, $10 \mathrm{ml}$ of an osmoticant (mannitol @ 1\%) was added to impart the substrate a higher moisture retaining property. The polypropylene bags after thorough mixing were incubated at $28 \pm 1$ ${ }^{\circ} \mathrm{C}$ for 7 days.

Evaluation of different $\boldsymbol{P}$. fluorescens based bio formulation against bacterial wilt of solanaceous crops

Different $P$. fluorescens based bio formulation was applied as seed treatment, root treatment and soil application to evaluate the efficacy of the antagonists in controlling the bacterial wilt in tomato, brinjal and chilli crops. For seed treatment, paste slurry of each substrate based formulation was prepared by mixing $100 \mathrm{~g}$ of the formulation in $200 \mathrm{ml}$ of water. To the paste slurry, tomato, brinjal and chilli seeds were dipped @ 1000 seed/100 ml of paste solution for $1 \mathrm{hr}$ to coat the seed with the formulations. The coated seeds were then removed from the slurry and spread over a paper in cool and dry place (under shade for overnight) for drying. Treated seeds are then sown in the nursery.

For root treatment, each of the substrate based formulations was mixed with water@ $20 \mathrm{~g}$ in $1000 \mathrm{ml}$ to prepare 2 per cent bio formulation solution. At the time of transplanting uprooted plants from nursery were root dipped (@1000seedlings/1000 ml) in the solution for 
$1 \mathrm{~h}$. treated seedlings were dried under shade for $1 \mathrm{~h}$ before transplanting in to earthen pots. For soil application, each of the substrate based formulations was mixed with soil contained in earthen pots @ 5\% solution. The mixture was applied @ $100 \mathrm{ml} / \mathrm{pot}$ (containing $20 \mathrm{~kg}$ of garden soil) after 15 days of sowing, at the base of the plants. After application of formulation, it was kept under net house to protect from direct exposure to sunlight. Five replications for each treatment with 5 plants per replication was maintained. The tomato, brinjal and chilli plants challenged with $R$. solanacearum cell suspension@108cfu/mL by following root inoculation technique (Blair et al., 1971). The controls included only the pathogen inoculated treatment (inoculated control). The number of wilted plants in each treatment was continuously recorded up to 90 days after inoculation with pathogen. The number of completely wilted plants was tabulated for each formulation and he percent (\%) wilt incidence was calculated.

For quantitative determination of pathogen and antagonist population in the rhizosphere soil, the population of the antagonist and the pathogen in the pot soil was estimated 90 days after transplanting following the serial dilution plate technique. The correlation studies between percent wilt incidence (PWI) and population of $P$. fluorescens and also between $P$. fluorescens and the pathogen $R$. solanacearum were also carried out.

\section{Results and Discussion}

Different strains of wilt pathogen $R$. solanacearum isolated from bacterial wilt infected tomato, brinjal and chilli plant from Assam were found to be basically similar in relation to their morphological and biochemical properties (Table 3). In TTC medium, the colony showed virulent creamy white /whitish fluidal irregular round colonies with light pink centre; which are the characters of virulent $R$. solanacearum. The pathogenicity tests established the isolated bacteria from wilted tomato, brinjal and chilli plants were different strains of $R$. solanacearum, the causative agent of bacterial wilt disease.

Altogether, 25 isolates of $P$. fluorescens associated rhizosphere soils of Assam were collected, out of which, five (5) isolates were found to produce fluorescent yellow-green or bluish green diffusible pigment of variable intensities on KMB medium under UV light (Table 1). Earlier studies suggest that fluorescent Pseudomonads are most active and dominant bacteria inhabiting the rhizosphere of diverse crop plants that could produce fluorescent yellow green diffusible pigment on specific medium like KMB (Reddy and Rao, 2009).

Morphologically, P. fluorescens are gram's negative short rods with a variation of size from 0.6 to $0.8 \mu \mathrm{m} \times 1.7$ to $1.9 \mu \mathrm{m}$. Colonies were circular convex with smooth and glistening surface, shiny water soluble and fluorescently pigmented appearance under UV light (Table 3). Biochemically, all native isolates of $P$. fluorescens showed similar results with regard to $\mathrm{KOH}$ test $(+)$, catalase $(+)$, arginine dehydrolase $(+)$, oxidase $(+)$, gelatin liquefaction $(+)$, dextrose utilization $(+)$, citrate utilization $(+)$, fluorescent pigment production $(+)$, growth at $4^{\circ} \mathrm{C}(+)$, growth at $27^{\circ} \mathrm{C}(+)$ and starch hydrolysis (-). However other biochemical tests like levan formation, denitrification, and $\mathrm{H}_{2} \mathrm{~S}$ gas production tests showed variation in reaction. Earlier, Kuarabachew et al., (2007) characterized fluorescent Pseudomonads on the basis of biochemical tests such as fluorescent production, levan formation, certain carbohydrate utilizations and morphological features of the isolates. 
Results of biochemical tests recorded were compared with the similar tests outlined for beneficial bacteria (Holt et al., 2000) and they were tentatively placed in biovar I, II and III (Table 5). On the basis of the results of levan, formation, denitrification and $\mathrm{H} 2 \mathrm{~S}$ gas production tests, $P$. fluorescens isolates were placed under three biovars. The isolates were also found $\mathrm{HCN}$ and siderophore positive for all five isolates (Table 3). Pf-A8 produced highest $(80.86 \%)$ siderophore followed by PfA2 (76.39 \%). Siderophore play an important role in the plant growth because of their ability to supply iron (Ramos-Solano et al., 2010).On the other hand, Ramette et al., (2003) reported that $\mathrm{HCN}$ was a broad spectrum antimicrobial compound involved in biological control of root diseases by many plant associated fluorescent pseudomonads.

The result of inhibitions produced (Table 2) by different isolates of $P$. fluorescens against Tomato $R$. solanacearum revealed that the highest inhibition was produced by isolate Pf-
A8 with suppression of 76.0 per cent growth, followed by Pf-A6 with 67.0 per cent growth suppression. In case of Brinjal $R$. solanacearum, the highest inhibition was produced by isolate Pf-A8 with suppression of 63.0 per cent growth followed by isolate Pf-A1 with suppression of 60.0 per cent growth. Similarly, in case of Chilli $R$. solanacearum, isolate Pf-A8 produced highest inhibition followed by isolate Pf-A1 with suppression of 72.2 per cent and 48.9 per cent growth, respectively. The antagonistic ability of Pf isolates might be due to the production of secondary metabolites like siderophore, hydrogen cyanide and due to the production of antibiotics like 2-4-diacetylphloroglucinol (DAPG), pyrrolnitrin (PRN), pyoluteorin (PLT), etc. (Hass and Keel (2003). Earlier, Nath et al., (2015) screened the antagonistic potential of bioactive microorganisms like $P$. fluorescens under in vitro condition and observed highest inhibition of 57.70 per cent against $R$. solanacearum.

Table.1 Sources of $R$. solanacearum isolates associated with rhizospheric soils of Assam

\begin{tabular}{cccc}
\hline Isolated code & Species & Origin/District & Rhizospheric Soil of Associated Plant \\
\hline PfA1 & P. fluorescens & Jorhat & Rice \\
PfA4 & P. fluorescens & Bokakhat & Teak \\
PfA6 & P. fluorescens & Karbianglong & Wild Banana \\
PfA7 & P. fluorescens & Karbianglong & Mango \\
PfA8 & P. fluorescens & Karbianglong & Pineapple \\
\hline
\end{tabular}

Table.4 Suppression of $R$. solanacearum of tomato, brinjal and chilli (cm diam.) by different $P$. fluorescens after $120 \mathrm{~h}$ of incubation in vitro

\begin{tabular}{|c|c|c|c|c|c|c|}
\hline \multirow[b]{2}{*}{$\begin{array}{l}\text { P. fluorescens } \\
\text { Strains }\end{array}$} & \multicolumn{2}{|c|}{$\begin{array}{l}\text { R. solanacearum } \\
\text { (Tomato) }\end{array}$} & \multicolumn{2}{|c|}{$\begin{array}{c}\text { R. solanacearum } \\
\text { (Brinjal) }\end{array}$} & \multicolumn{2}{|c|}{$\begin{array}{c}\text { R. solanacearum } \\
\text { (Chilli) }\end{array}$} \\
\hline & $\begin{array}{c}\text { Colony } \\
\text { diam. }(\mathrm{cm}) \\
\text { after } 120 \mathrm{~h}\end{array}$ & $\begin{array}{c}\text { Growth } \\
\text { suppression } \\
(\%)\end{array}$ & $\begin{array}{l}\text { Colony } \\
\text { diam. }(\mathrm{cm}) \\
\text { after } 120 \mathrm{~h}\end{array}$ & $\begin{array}{l}\text { Growth } \\
\text { suppression } \\
(\%)\end{array}$ & $\begin{array}{l}\text { Colony } \\
\text { diam. }(\mathrm{cm}) \\
\text { after } 120 \mathrm{~h}\end{array}$ & $\begin{array}{l}\text { Growth } \\
\text { suppression } \\
(\%)\end{array}$ \\
\hline$P f-\mathrm{A} 1$ & 4.1 & 46 & 5.4 & 60 & 4.4 & 48.9 \\
\hline$P f-\mathrm{A} 4$ & 4.1 & 46 & 4.2 & 38 & 4.0 & 44.4 \\
\hline$P f-\mathrm{A} 6$ & 6.0 & 67 & 5.7 & 47 & 4.1 & 45.6 \\
\hline$P f-\mathrm{A} 7$ & 3.8 & 42 & 3.6 & 40 & 4.3 & 47.8 \\
\hline$P f-\mathrm{A} 8$ & 6.8 & 76 & 3.4 & 63 & 6.5 & 72.2 \\
\hline S.Ed & 0.7 & & 0.6 & & 0.5 & \\
\hline $\mathrm{CD}$ & 1.2 & & 1.0 & & 0.9 & \\
\hline
\end{tabular}


Table.2 Morphological and biochemical characters of different Pseudomonas fluorescens (Pf) and Ralstonia solanacearum (Rs)

\begin{tabular}{lcccccccc}
\hline \multicolumn{1}{c}{ Test/ Isolates } & $\boldsymbol{P f A}$ & $\boldsymbol{P f A}$ & $\boldsymbol{P f A}$ & $\boldsymbol{P f A}$ & $\boldsymbol{P f A}$ & $\boldsymbol{R s}$ & $\boldsymbol{R s}$ & $\boldsymbol{R s}$ \\
& $\mathbf{1}$ & $\mathbf{4}$ & $\mathbf{6}$ & $\mathbf{7}$ & $\mathbf{8}$ & (Tomato) & (Brinjal) & (Chilli) \\
\hline Colony elevation & $\mathrm{C}$ & $\mathrm{C}$ & $\mathrm{C}$ & $\mathrm{C}$ & $\mathrm{C}$ & $\mathrm{C}$ & $\mathrm{C}$ & $\mathrm{C}$ \\
Colony edge & $\mathrm{O}$ & $\mathrm{O}$ & $\mathrm{O}$ & $\mathrm{O}$ & $\mathrm{O}$ & $\mathrm{O}$ & $\mathrm{O}$ & $\mathrm{O}$ \\
Surface \& water soluble & $\mathrm{S}+$ & $\mathrm{S}+$ & $\mathrm{S}+$ & $\mathrm{S}+$ & $\mathrm{S}+$ & $\mathrm{S}+$ & $\mathrm{S}+$ & $\mathrm{S}+$ \\
Gram stain & - & - & - & - & - & - & - & - \\
Shape of cell & $\mathrm{R}$ & $\mathrm{R}$ & $\mathrm{R}$ & $\mathrm{R}$ & $\mathrm{R}$ & $\mathrm{R}$ & $\mathrm{R}$ & $\mathrm{R}$ \\
Spore formation & - & - & - & - & - & - & - & - \\
Motility & + & + & + & + & + & + & + & + \\
7\% NaCl & + & + & + & + & + & - & - & - \\
Fl. pigment & + & + & + & + & + & - & - & - \\
KOH & + & + & + & + & + & + & + & + \\
Catalase & + & + & + & + & + & + & + & + \\
Oxidase & + & + & + & + & + & + & + & + \\
Gas prod & - & - & + & - & - & + & + & + \\
Starch hydrolyse & - & - & - & - & - & - & - & - \\
Gelatin hydrolyse & + & + & + & + & + & - & - & - \\
Dextrose utilize & + & + & + & + & + & + & + & + \\
Growth at $4{ }^{\circ} \mathrm{C}$ & + & + & + & + & + & + & + & + \\
Growth at $41^{\circ} \mathrm{C}$ & - & - & - & - & - & - & - & - \\
Growth at $27^{\circ} \mathrm{C}$ & + & + & + & + & + & + & + & + \\
Levan prod & + & + & + & + & - & - & - & - \\
Arginine hydrolyse & + & + & + & + & + & - & - & - \\
Citrate utilize & + & + & + & + & + & + & + & + \\
Denitrification & - & - & + & - & + & + & + & + \\
HCN & + & + & + & + & + & - & - & - \\
Siderophore $(\%)$ & 75 & 76 & 70 & 75 & 81 & - & - & - \\
\hline C & & +
\end{tabular}

$\mathrm{C}=$ convex, $\mathrm{O}=$ round, $\mathrm{S}+=$ smooth, glistening and water soluble, $\mathrm{R}=$ rod shaped, -=negative and $+=$ positive

Table.5 Effect of different $P$. fluorescens based bioformulation on bacterial wilt incidence (\%), population dynamics of $R$. solanacearum and $P$. fluorescens $\left(1 \times 10^{9} \mathrm{cfu} / \mathrm{g}\right)$ in tomato rhizosphere after 90 days of transplanting (DAT)

\begin{tabular}{llll}
\hline \multicolumn{1}{c}{ Treatment } & \multicolumn{1}{c}{$\begin{array}{c}\text { Wilt incidence } \\
(\boldsymbol{\%})^{*}\end{array}$} & $\begin{array}{c}\text { Population density } \\
\text { of } \boldsymbol{P} . \boldsymbol{f l}^{* *}\end{array}$ & $\begin{array}{c}\text { Population density } \\
\text { of } \boldsymbol{R} . \mathbf{s o l} \boldsymbol{l}^{* *}\end{array}$ \\
\hline T1: $P f$-A1 & $2.0(8.13)$ & $14.68(1.17)$ & $0.56(-0.25)$ \\
T2: $P f$-A4 & $32.0(34.45)$ & $8.54(0.93)$ & $4.74(0.67)$ \\
T3: $P f$-A6 & $1.0(5.74)$ & $15.3(1.18)$ & $1.2(0.08)$ \\
T4: $P f$-A7 & $18.5(25.47)$ & $9.7(0.97)$ & $2.8(0.45)$ \\
T5: $P f$-A8 & $1.0(5.74)$ & $15.92(1.20)$ & $0.24(-0.62)$ \\
T6: Inoculated control & $76.0(60.60)$ & $0.02(-1.7)$ & $19.66(1.29)$ \\
\hline S.Ed & 0.05 & 0.05 & 0.12 \\
CD & 0.08 & 0.08 & 0.21 \\
\hline
\end{tabular}

$*=$ angular transformed value, $* *=\operatorname{logarithm}$ transformed value 
Table.3 Differentiation of $P$. fluorescens based on phenotypic characterizations

\begin{tabular}{cc}
\hline Type of Biovar & Strains of $\boldsymbol{P}$. fluorescens \\
\hline Biovar I & $P f$-A1,Pf-A4 and $P f$-A7 (3) \\
Biovar II & $P f$-A6 (1) \\
Biovar III & $P f$-A8 (1) \\
\hline
\end{tabular}

Table.6 Effect of different $P$. fluorescens based bioformulation on bacterial wilt incidence (\%), population dynamics of $R$. solanacearum and $P$. fluorescens $\left(1 \times 10^{9} \mathrm{cfu} / \mathrm{g}\right)$

In brinjal rhizosphere after 90 DAT

\begin{tabular}{llll}
\hline \multicolumn{1}{c}{ Treatment } & \multicolumn{1}{c}{$\begin{array}{c}\text { Wilt incidence } \\
(\boldsymbol{\%})^{*}\end{array}$} & $\begin{array}{c}\text { Population density } \\
\text { of } \boldsymbol{P} . \boldsymbol{f} l^{* *}\end{array}$ & $\begin{array}{c}\text { Population density } \\
\text { of } \boldsymbol{R} . \mathbf{s o l} * * *\end{array}$ \\
\hline T1: $P f$-A1 & $2(8.13)$ & $15.8(1.20)$ & $0.33(-0.49)$ \\
T2: $P f$-A4 & $12.0(20.27)$ & $10.78(1.03)$ & $3.58(0.55)$ \\
T3: $P f$-A6 & $8.0(16.43)$ & $13.48(1.13)$ & $1.70(0.23)$ \\
T4: $P f$-A7 & $11.0(19.37)$ & $10.3(1.01)$ & $2.87(0.46)$ \\
T5: $P f$-A8 & $4.0(11.54)$ & $14.28(1.15)$ & $1.88(0.27)$ \\
T6: Inoculated control & $68.0(55.55)$ & $0.03(-1.52)$ & $19.02(1.28)$ \\
\hline S.Ed & 0.07 & 0.07 & 0.19 \\
CD & 0.12 & 0.12 & 0.33 \\
\hline
\end{tabular}

*=angular transformed value, ${ }^{* *}=\log$ arithm transformed value

Table.7 Effect of different $P$. fluorescens based bioformulation on bacterial wilt incidence (\%), population dynamics of $R$. solanacearum and $P$. fluorescens $\left(1 \times 10^{9} \mathrm{cfu} / \mathrm{g}\right)$ In chilli rhizosphere after 90 DAT

\begin{tabular}{llll}
\hline \multicolumn{1}{c}{ Treatment } & \multicolumn{1}{c}{$\begin{array}{c}\text { Wilt incidence } \\
(\boldsymbol{\%})^{*}\end{array}$} & $\begin{array}{c}\text { Population density } \\
\text { of } \boldsymbol{P} . f^{* *}\end{array}$ & $\begin{array}{c}\text { Population density } \\
\text { of } \boldsymbol{R} . \mathbf{s o l} \boldsymbol{l}^{* *}\end{array}$ \\
\hline T1: Pf-A1 & $4.0(11.54)$ & $13.92(1.14)$ & $1.74(0.24)$ \\
T2: Pf-A4 & $12.0(20.27)$ & $6.94(0.84)$ & $6.00(0.78)$ \\
T3: Pf-A6 & $9.8(18.24)$ & $14.4(1.16)$ & $1(0.00)$ \\
T4: Pf-A7 & $11.0(19.37)$ & $11.26(1.05)$ & $3.4(0.53)$ \\
T5: Pf-A8 & $2.0(8.13)$ & $15.12(1.18)$ & $1.36(0.13)$ \\
T6: Inoculated control & $72.0(58.05)$ & $0.02(-1.7)$ & $18.44(1.26)$ \\
\hline S.Ed & 0.07 & 0.07 & 0.16 \\
CD & 0.12 & 0.12 & 0.28 \\
\hline
\end{tabular}

$*=$ angular transformed value, $* *=\log$ arithm transformed value 
Fig.1 Correlation between the population density of $P$. fluorescens and PWI in tomato, brinjal and chilli rhizosphere soil

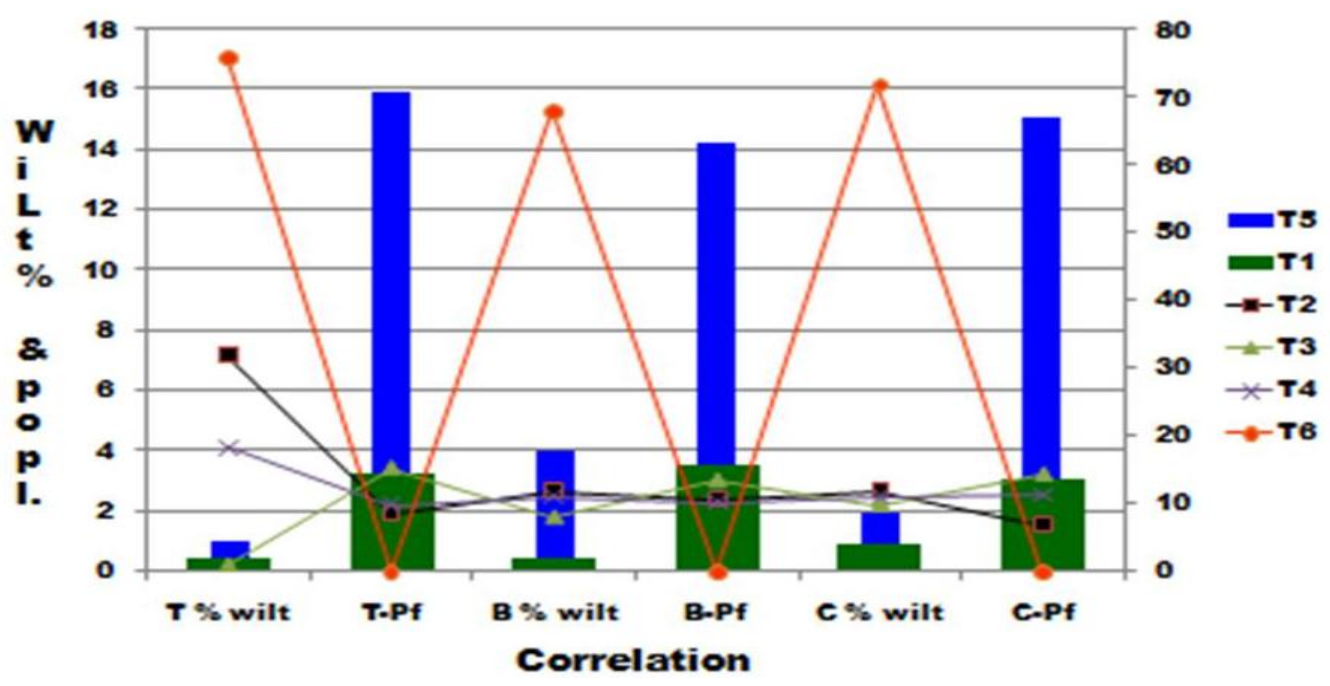

The result of the effects of $P$. fluorescens based bio formulation in vivo revealed that the wilt incidence in tomato, brinjal and chilli decreased significantly by different bio formulations compared to inoculated control. The lowest wilt incidence in tomato $(1.0 \%)$ was recorded in the treatment with Pf-A 8 based bio formulation and Pf-A6 based bio formulation applied as seed treatment, root treatment and soil application followed by PfA1 based bio formulation (2.0\%) (Table 4). Tomato plants treated with only $R$. solanacearum (inoculated control) showed highest disease incidence $(76.0 \%)$. In brinjal plants, the lowest disease incidence was exhibited by the bio formulation Pf-A1 based bio formulation $(2.0 \%)$ followed by Pf-A8 based bio formulation $(4.0 \%)$ and Pf-A6 based bio formulation (8.0\%) (Table 6). Brinjal plants treated with only $R$. solanacearum (inoculated control) showed highest disease incidence $(68.0 \%)$. Similarly, the lowest disease incidence in chilli treated plants was exhibited by the bio formulation Pf-A8 (2\%) followed by Pf-A1 based bio formulation (4\%) and Pf-A6 based bio formulation (9.8\%) (Table 7). Chilli plants treated with only $R$. solanacearum showed highest disease incidence $(72.0 \%)$. The results are found in agreement with Bora and Deka (2007) who found that application of $P$. fluorescens based biopesticide (Biofor-Pf) as combination of seed treatment, root application and soil application at transplanting showed minimum wilt incidence.

The reduced in incidence of $R$. solanacearum up to 50 per cent in banana, 49 per cent in brinjal and 36 per cent in tomato due to $P$. fluorescens treatment was also recorded by Anuratha and Gnanamanickan (1990). Srivastava et al., (2010), Nath et al., (2015) also obtained significant reduction in bacterial wilt incidence in solanaceous crop by application of $P$. fluorescens alone or in consortia. For the effective management of any soil borne disease, the introduced antagonist should colonize root (Weller, 1984). Root zone application of $P$. fluorescens increased rhizosphere population of the bacteria since some of these strains have the ability to colonize the roots (Vidhyasekaran and Muthamilan, (1995).

Results of the population dynamics of $R$. solanacearum and $P$. fluorescens in the rhizosphere soil of tomato, brinjal and chilli 
assayed 90 days after transplanting (DAT) are presented in tables 4, 6 and 7, respectively. Population dynamics of $P$. fluorescens in rhizosphere soil showed significant increase in all treatments as compared to inoculated controls. Corresponding to the enhancement of $P$. fluorescens population in the treated rhizosphere soil there was decline of $R$. solanacearum population. Similar phenomenon was observed by Bustamante et al., (1989), when they recorded reduction of $R$. solanacearum population with corresponding increase in $P$. fluorescens population in the rhizosphere.

The correlation studies established a negative correlation between the size of $P$. fluorescens population and per cent wilt incidence in tomato, brinjal and chilli (Fig. 1). Although the correlation values were found statistically non-significant, negative correlation indicated that with increase in the size of antagonists population there was corresponding decrease in the PWI in the plants that maybe due to the fact that higher population of antagonists and their activities resulted either in suppression of the pathogen population or exclusion of pathogens from soil rhizosphere. Bora and Deka (2007); Chakravarty and Kalita (2012) observed similar phenomenon in tomato and brinjal, when they recorded negative correlation between $P$. fluorescens and PWI as well as between population densities of $R$. solanacearum and P. fluorescens. Nath et al., (2016) observed negative correlation between bacterial wilt incidence and yield of tomato. Earlier, Weller and Cook (1983) also correlated the influence of antagonist population with suppression of disease incidence, and they suggested that $P$. fluorescens inhibit pathogens by competing with them for nutrients or by producing siderophore, antibiotics or $\mathrm{HCN}$ and May also produce substances that stimulates plant growth. The finding furthers supports the biocontrol properties of the antagonistic strain
$P$. fluorescens. In addition to the environmental factors, the PWI is chiefly dependent on the population of $R$. solanacearum in the soil.

\section{Acknowledgements}

The authors are highly grateful to AAU, Jorhat for providing facilities and Maulana Azad National Fellowship for Minority Students, UGC for financial assistance to carry out the study.

\section{References}

Anuratha, C. S. and Gnanamanickam, S. S. 1990. Biological control of bacterial wilt caused by Pseudomonas solanacearum in India with antagonistic bacteria. Plant Soil. 124:109-116.

Blair, J.E., Lenette, E.H. and Truant, J.P. 1971. In: Laboratory Exercise in Microbiology. (Eds. M.J Pleczer and E.C Chan). Mc. Graw Hill Book Co., Berlin. Pp. 356.

Bora, L.C. and Deka, S.N. 2007. Wilt disease suppression and yield enhancement in tomato (Lycopersicon esculentum) by application of Pseudomonas fluorescens based bio pesticide (Biofor-Pf) in Assam. Indian J. Agric. Sc. 77(8): 490494.

Bustamanate, G. P., Ciampi-Panno, L. and Guaiquil, G. V. 1989. Inhibition in vitro of Pseudomonas solanacearum E.F. Smith using antagonistic strains of Pseudomonas fluorescens. Revista de. Microbiologia (Abstr.).

Chakravarty, G. and Kalita, M. C. 2012. Biocontrol potential of Pseudomonas fluorescens against bacterial wilt of Brinjal and its possible plant growth promoting effects. Ann. Biol. Res. 3 (11):5083-5094.

French, E.R. and Sequeira, L. 1970. Strains of Pseudomonas solanacearum from 
Central and South America: a comparative study. Phytopathol. 60:506-512.

Haas, D. and Keel, C. 2003. Regulation of antibiotic production in root-colonizing Pseudomonas spp. and relevance for biological control of plant disease. Ann. Rev. Phytopathol. 41: 117- 153.

Hayward, A. C. 1991. Biology and epidemiology of bacterial wilt caused by Pseudomonas solanacearum. Ann. Rev. Phytopathol. 29:65-89.

Hayward, A. C. 1994. Systematics and phylogeny of Pseudomonas solanacearum and related bacteria. In: Bacterial Wilt: the Disease and its Causative Agent, Pseudomonas solanacearum. Hayward, A. C.; Hartman, G. L. (Ed.) Wallingford, UK: CABI. Pp. 123-136.

Holt, J.G., Krieg, N.R., Sneath, P.H.A., Staley, J.T. and Williams, S.T. 2000. Bergey's Manual of Determinative Bacteriology, 9thEdn. Lippincott Williams and Wilkins Philadelphia, USA.. Pp: 152-169.

Kishun, R. 1989. Loss in yield of tomato due to bacterial wilt caused by Pseudomonas solanacearum. Indian Phytopath. 44:152-155.

Kuarabachew, H., Assefa, F. and Hiskias, Y. 2007. Evaluation of Ethopian isolates of Pseudomonas fluorescensas biocontrol agent against potato bacterial wilt caused by Ralstonia solanacearum. Acta Agriculturae Slovenica. 90(2):125135.

Maki, L., Miranda, B., Michael, L., Kam, T. and Qin, W. 2011. Characterization of some efficient cellulose producing bacteria isolated from paper mill sludges and organic fertilizers. Int. J. Biochem. Mol. Biol. 2(2):146-154.

Nath, B.C., Bora, L.C., Kataki, L., Talukdar, K., Sharma, P., Dutta, J. and Khan, P. 2016. Plant Growth Promoting
Microbes, their compatibility analysis and utility in biointensive management of bacterial wilt of tomato. Int. J. Curr. Microbiol. App. Sci. 5(6):1007-1016.

Nath, B.C., Bora, L.C., Malemnganba, K. and Bora, G.C. 2015. Assessment of resistance in ance in ance in tomato genotypes to genotypes against bacterial wilt disease ( $R$. solanacearum) in Assam condition. The Bioscan. 10(4): 1889-1893.

Payne, S. M. 1994. Detection, isolation and characterization of siderophore. Methods Enzymology.235:329-344.

Ramette, A., Moënne-Loccoz, Y. and Défago, G. 2003. Prevalence of fluorescent pseudomonads producing antifungal phloroglucinols and/or hydrogen cyanide in soils naturally suppressive or conducive to tobacco black root rot. FEMS Microbiol Ecol. 44(1):35-43.

Reddy, P. B. and Rao, K. S. 2009. Biochemical and PCR-RAPD characterization of Pseudomonas fluorescens produced antifungal compounds inhibit the rice fungal pathogens in vitro. EJEAF Che. 8(10):1062-1067.

Ramos-Solano, B., García, J.A.L., GarciaVillaraco, A., Algar, E., GarciaCristobal, J. and Mañero, F.J.G. 2010.Siderophore and chitinase producing isolates from the rhizosphere of Nicotia naglauca Graham enhance growth and induce systemic resistance in Solanum lycopersicum L. Plant Soil. 334:189-197.

Srivastava R., Khalid, A., Singh, U.S. and Sharma, A.K. 2010.Evaluation of arbuscular mycorrhizal fungus, fluorescent Pseudomonas and Trichoderma harzianum formulation against Fusarium oxysporum f.sp. lycopersici for the management of tomato wilt. Biol. Cont. 53(1): 24-31. 
Vidhyasekaran, P. and Muthamilan, M. 1995. Development of formulations of Pseudomonas fluorescence for control of chickpea wilt. Plant Dis. 79:782-786.

Wei, G., Kloepper, J.W. and Tuzun, S. 1996. Induced systemic resistance to cucumber diseases and increased plant growth by plant growth promoting rhizobacteria under field conditions. Phytopathol. 86: 221-224.
Weller, D.M. and Cook, R.S. 1983. Suppression of take all wheat by seed treatments with fluorescent Pseudomonads. Phytopathol. 73: 463469.

Winstead, N.N and Kelman, A. 1952.Inoculation technique for evaluating resistance to $R$. solanacearum (Pseudomonas solanacearum). Phytopathol. 42:628634.

\section{How to cite this article:}

Thalhun L. Kipgen and Bora, L.C. 2017. Biochemical Differentiation of Pseudomonas fluorescens of Assam Soil and their Utility in Management of Bacterial Wilt of Solanaceous Crops. Int.J.Curr.Microbiol.App.Sci. 6(6): 2796-2806. doi: https://doi.org/10.20546/ijcmas.2017.606.333 